Current psychology letters

\title{
Grammatical Gender is also on the Tip of French Tongues
}

L. Ferrand

\section{(2) OpenEdition}

1 Journals

Electronic version

URL: http://journals.openedition.org/cpl/226

DOI: $10.4000 / \mathrm{cpl} .226$

ISSN: $1379-6100$

Publisher

Centre PsyCLÉ

Printed version

Date of publication: 1 August 2001

\section{Electronic reference}

L. Ferrand, «Grammatical Gender is also on the Tip of French Tongues », Current psychology letters

[Online], 2001/2, 5 | 2001, Online since 16 September 2003, connection on 08 September 2020. URL http://journals.openedition.org/cpl/226 ; DOl : https://doi.org/10.4000/cpl.226

This text was automatically generated on 8 September 2020

(C) All rights reserved 


\section{Grammatical Gender is also on the} Tip of French Tongues

L. Ferrand 